\title{
THE SIGNAL PEPTIDE CLEAVAGE SITE OF A B1 HORDEIN DETERMINED BY RADIOSEQUENCING OF THE IN VITRO SYNTHESIZED AND PROCESSED POLYPEPTIDE
}

by

\author{
VERENA CAMERON-MILLS and SUSAN M. MADRID
}

Department of Physiology, Carlsberg Laboratory, Gamle Carlsberg Vej 10, DK-2500 Copenhagen Valby

Keywords: Coupled transcription-translation, N-chlorosuccinimide cleavage, SDS-PAGE.

\begin{abstract}
The major storage proteins which accumulate in the endosperm of the developing barley grain are the hordein polypeptides. They are synthesized on membrane-bound polysomes and co-translationally transported into the lumen of the ER and are ultimately deposited in the vacuole. The processing step, which accompanies transport across the ER membrane, was studied in vitro with the B1 hordein gene, $\lambda$ hor 2-4 in the expression plasmid pDS6. Microsomes were prepared from barley endosperm which transported and processed the B1 hordein polypeptide to a mature form with a high degree of efficiency. Because the $\mathrm{B} 1$ hordein was previously found to be $\mathrm{NH}_{2}$-terminally blocked, the site of processing was unknown. The in vitro synthesized precursor and processed $\mathrm{B} 1$ hordein polypeptides were subjected to $\mathrm{N}$-chlorosuccinimide peptide mapping and $\mathrm{NH}_{2}$-terminal radiosequencing. The signal peptide cleavage site, predicted from the deduced amino acid sequence, was confirmed.
\end{abstract}

\section{INTRODUCTION}

The major storage proteins found in the endosperm tissue of barley seeds are the alcoholsoluble prolamins, hordein. Hordein is composed of at least 4 classes of proteins, namely $B$, $\mathrm{C}, \mathrm{D}$ and $\gamma$ hordein, which are coordinately synthesized during endosperm development $(15,30)$. The isolation and characterization of genomic clones encoding members of B (6), C (12) and $\gamma$ hordein (8) polypeptide classes have made it possible to examine the synthesis, processing and structure of these storage proteins in greater detail.
The hordein polypeptides were first shown to be synthesized on membrane-bound polysomes, with primary translation products approximately $2 \mathrm{kd}$ larger than the mature proteins, by BRANDT and INGVERSEN $(4,5)$. In vitro translation of isolated membrane-bound polysomes from barley endosperm, reconstituted with stripped microsomal membranes, revealed that hordein polypeptides are co-translationally processed and transported into the lumen of the endoplasmic reticulum (31).

In order to examine the co-translational transport and processing events in greater detail the

Abbreviations: DTT = dithiothreitol; $\mathrm{kD}=$ kilodalton; $\mathrm{NCS}=\mathrm{N}$-chlorosuccinimide; $\mathrm{PK}=$ proteinase K; PMSF = phenylmethylsulfonylfluorid; PVDF = polyvinylidene difluoride; $R E R=$ rough endoplasmic reticulum; $R M=$ rough microsomes; RM-N = rough microsomes - nuclease treated; SDS-PAGE = sodium dodecyl sulphate-polyacrylamide gel electrophoresis. 
technique of coupled transcription-translation, with the in vitro synthesis of a single protein, was exploited. The $\mathrm{B} 1$ hordein gene $\lambda$ hor $2-4$, characterized by BRANDT et al. (6), has been cloned in the expression vector pDS6 (29). The first 19 amino acids in the deduced amino acid sequence from the B1 hordein gene have the common features of a signal peptide, namely a charged lysine adjacent to the initiator methionine and a hydrophobic core sequence (17). However, the absence of $\mathrm{NH}_{2}$-terminal sequence data for mature BI hordein, due to $\mathrm{NH}_{2}$-terminal blocking (26), leaves the predicted cleavage site unconfirmed. In the present work the B1 hordein gene, transcribed and translated in vitro, was shown to encode a precursor with a 19 amino acid signal peptide which was co-translationally processed by barley RER membranes to a mature form. The cleavage of the signal peptide was shown by $\mathrm{N}$-chlorosuccinimide peptide mapping. The $\mathrm{NH}_{2}$-terminus of the mature $\mathrm{B} 1$ hordein was determined by radiosequencing, taking advantage of new techniques in SDS-PAGE and protein sample preparation which reduce the occurrence of $\mathrm{NH}_{2}$-terminus blocking reactions (22).

\section{MATERIALS AND METHODS}

\subsection{Plant Material}

Barley plants (Hordeum vulgare L.) cv. Bomi were grown in the field. Spikes were harvested 20 days after anthesis, immediately frozen in liquid nitrogen, and stored at $-80^{\circ} \mathrm{C}$.

\subsection{Isolation and translation of poly $\mathbf{A}^{+} \mathbf{R N A}$}

Total RNA was prepared from developing barley endosperms according to AVIV and LEDER (2) with minor modifications. The frozen ground tissue was extracted in $0.1 \mathrm{M}$ Tris- $\mathrm{HCl}$ pH 9.0, 10 mM EDTA, 25 mM DTT and 1\% SDS together with an equal volume of phenol, and the RNA precipitated from the aqueous phase with $2 \mathrm{M} \mathrm{LiCl}$ at $-20^{\circ} \mathrm{C}$.

Poly $\mathrm{A}^{+} \mathrm{RNA}$ was isolated from the total RNA preparation by Poly(U)-Sepharose 4B (Pharmacia) affinity chromotography and translated in a wheat germ extract (24), as described by BRANDT and INGVERSEN (5).

\subsection{Immune precipitation of hordein polypep- tides from cell-free translations}

Polyclonal $\mathrm{IgG}$ antibodies raised against hordein from Hordeum vulgare cv. Bomi by DiERKS-VENTLING and Cozens (11) were a gift. Immunoprecipitation of hordein polypeptides from poly $\mathrm{A}^{+} \mathrm{RNA}$ translations in the wheat germ system was performed according to ANDERSON and BLOBEL (1). Translation assays of 25 $\mu \mathrm{l}$, solubilized in $1 \% \mathrm{SDS}$, were incubated with $50 \mu \mathrm{g}$ anti-hordein IgG and the antigen-IgG complex coupled to the immunoabsorbant Protein A-Sepharose CL-4B (Pharmacia) as described (1). The antigens were subsequently released by boiling the Protein A-Sepharose beads in $20 \mu \mathrm{l}$ of $125 \mathrm{~mm}$ Tris- $\mathrm{HCl} \mathrm{pH} 6.8,2.5 \%$ SDS, $10 \%$ glycerol and $50 \mathrm{~mm}$ DTT and then acetylated with $70 \mathrm{~mm}$ iodoacetamide at $37^{\circ} \mathrm{C}$. The translation products were analysed by 10 $-15 \%$ gradient SDS-PAGE (19) and fluorography (10).

\subsection{Preparation of barley microsomal mem- branes}

Rough endoplasmic reticulum (RER) was isolated from developing barley endosperms according to a rapid procedure developed for maize endosperm tissue by BURR and BURR (7). The homogenized endosperm tissue, after a 10 min centrifigation at $3000 \times \mathrm{g}$ to remove cell debris and starch, was layered on a $35-70 \%$ sucrose gradient and centrifuged at $160,000 \times \mathrm{g}$ for 2 hours. The RER banded in the density gradient at $1.37 \mathrm{M}$ sucrose and was pelleted as described (7).

The RER microsomes (RM), suspended in 10 $\mathrm{mm}$ Hepes pH 7.6, $1 \mathrm{~mm} \mathrm{CaCl}, 20 \%$ glycerol and $1 \mathrm{~mm}$ DTT, were then treated with $15 \mathrm{U} / \mathrm{ml}$ of nuclease S7 (Boehringer Mannheim) for 10 min at $23{ }^{\circ} \mathrm{C}$. Nuclease activity was terminated by addition of EGTA to $4 \mathrm{mM}$ and the microsomes (RM-N) pelleted by a 30 min centrifigation at $100,000 \times \mathrm{g}$. Microsomes (RM and RM$\mathrm{N})$ were suspended in $10 \mathrm{~mm}$ Hepes $\mathrm{pH} 7.6,1$ mM EGTA and $1 \mathrm{~mm}$ DTT, at $100 \mathrm{~A}_{260} \mathrm{U} / \mathrm{ml}$ and stored at $-196{ }^{\circ} \mathrm{C}$ in aliquots for single use. 


\subsection{Plasmid constructs and preparation of plas- mid DNA}

The Bl hordein gene, $\lambda$ hor2-4 (6), was cloned into the expression plasmid pDS6 between the EcoRI and HindIII sites of the polylinker (S.M. MADRID, manuscript in preparation). The plasmid (pDS-hor2-4) was propogated in the E. coli host DH5a (16) in medium selective for ampicillin resistance. Plasmid DNA was prepared according to BIRNBOIM and DOLY (3), followed by $\mathrm{CsCl} /$ ethidium bromide equilibrium centrifugation (23).

\subsection{Coupled transcription-translation}

The $\mathrm{B} 1$ hordein gene in pDS6 was transcribed with E. coli RNA polymerase (Promega) in the presence of $7 \mathrm{mGpppA}$ to give capped $\mathrm{mRNA}$ and subsequently translated in the wheat germ system (24) as described by STUEBER et al. (29). The wheat germ extract was given an additional $30,000 \times \mathrm{g}$ centrifugation for $10 \mathrm{~min}$ immediately prior to the translation assay and the amount added was carefully titered to minimise polypeptide processing and transport activity of wheat germ origin. With the exception of translations performed for radiosequencing, the polypeptides were synthesized with $20 \mu \mathrm{C}$ of ${ }^{35} \mathrm{~S}$ methionine (sp. act. $1100 \mathrm{Ci} / \mathrm{mmol}$ ). RM-N microsomes were included in the translations where indicated at a final concentration of $7 \mathrm{~A}_{260}$ $\mathrm{U} / \mathrm{ml}$.

The reticulocyte lysate and dog pancreas microsomes were purchased from Amersham and translation of B1 hordein mRNA was performed according to Amersham protocols.

Post-translational proteinase K (PK) digestions were performed on $10 \mu \mathrm{l}$ aliquots of each $25 \mu l$ translation assay, by addition of $1 \mu \mathrm{l}$ of PK $(3 \mathrm{mg} / \mathrm{ml})$ and a $45 \mathrm{~min}$ incubation on ice. The digestions were terminated by addition of $1 \mu \mathrm{l}$ of $2 \%$ phenylmethylsulfonylfluorid (PMSF) in isopropanol.

The translation products ( $3 \mu 1$ aliquots) were analysed by $18 \%$ SDS-PAGE in the high-molarity Tris buffer system (14) on $0.75 \mathrm{~mm}$ thick Mini-PROTEAN II slab gels (Bio-Rad). The gels were subsequently fixed and prepared for fluorography (10).

\subsection{Peptide mapping with $\mathbf{N}$-chlorosuccinimide}

B1 hordein polypeptides, synthesized by coupled transcription-translation of the $\mathrm{B} 1$ hordein gene (see 2.6), were separated on a $0.75 \mathrm{~mm} 10 \%$ high-molarity Tris SDS-PAGE, and cut out from the dried gel, after localization by autoradiography. The gel slices were incubated at room temperature by shaking with the following solutions for $\mathrm{N}$-chlorosuccinimide (NCS) cleavage (20): 1. Two $10 \mathrm{~min}$ washes in $10 \mathrm{ml} \mathrm{H}_{2} \mathrm{O}, 2$. Two $10 \mathrm{~min}$ washes in $10 \mathrm{ml}$ urea/ $/ \mathrm{H}_{2} \mathrm{O} / \mathrm{CH}_{3} \mathrm{COOH}$ $(1 \mathrm{~g} / 1 \mathrm{ml} / 1 \mathrm{ml}), 3.30 \mathrm{~min}$ wash in $5 \mathrm{ml} 0.015 \mathrm{M}$ NCS in urea/ $\mathrm{H}_{2} \mathrm{O} / \mathrm{CH}_{3} \mathrm{COOH}, 4$. Two $10 \mathrm{~min}$ washes in $10 \mathrm{ml} \mathrm{H}_{2} \mathrm{O}$, 5. Three 30 min equilibrations in $10 \mathrm{ml}$ electrophoresis sample buffer: 0.0625 м Tris- $\mathrm{HCl} \mathrm{pH} 6.8,3 \%$ SDS, $10 \%$ glycerol and $15 \% \beta$-mercaptoethanol.

The NCS cleavage products were separated on an $18 \%$ high-Tris SDS-PAG, loading the gel slices into the slots of a $1 \mathrm{~mm}$ thick MiniPROTEAN slab gel. The gel was incubated in 1 M sodium salicylate in 50\% methanol and dried for autoradiography.

\subsection{B1 hordein radio-sequencing}

Precursor and mature B1 hordein polypeptides were synthesized in vitro (see 2.6) in the wheat germ system with or without barley microsomes. The translation products were labelled with $20 \mu \mathrm{C}$ of ${ }^{3} \mathrm{H}$ isoleucine (sp. act. 110 $\mathrm{Ci} / \mathrm{mmol}$ ) per $25 \mu \mathrm{l}$ assay. The $\mathrm{Bl}$ hordein polypeptides were purified for $\mathrm{NH}_{2}$-terminal sequencing using procedures, described below, to avoid $\mathrm{NH}_{2}$-terminal blockage resulting from the conversion of glutamine to pyroglutamate (6), and to attain high peptide recovery for radio-sequencing (22). The polypeptides were first separated by Tricine-SDS-PAGE as described by SCHÄGGER and VON JAGOW (27).

$10 \mu \mathrm{l}$ aliquots of the translation products were incubated for $30 \mathrm{~min}$ at $40{ }^{\circ} \mathrm{C}$ with sample buffer: $50 \mathrm{~mm}$ Tris- $\mathrm{HCl} \mathrm{pH} 6.8,12 \%$ glycerol, $4 \%$ SDS, $2 \% \beta$-mercaptoethanol and $0.01 \%$ Serva Blue G. The slab gels (1 mm thick) comprising a $15 \mathrm{~cm}$ separating gel $(7.5 \% \mathrm{~T}, 3 \%$ C) and a $3 \mathrm{~cm}$ stacking gel $(4 \% \mathrm{~T}, 3 \% \mathrm{C})$, were stored for 24 hours at room temperature to maximise acrylamide polymerization. Acryl- 
V. Cameron-Mills \& S.M. Madrid: B1 Hordein $\mathrm{NH}_{2}$-terminal Radiosequence

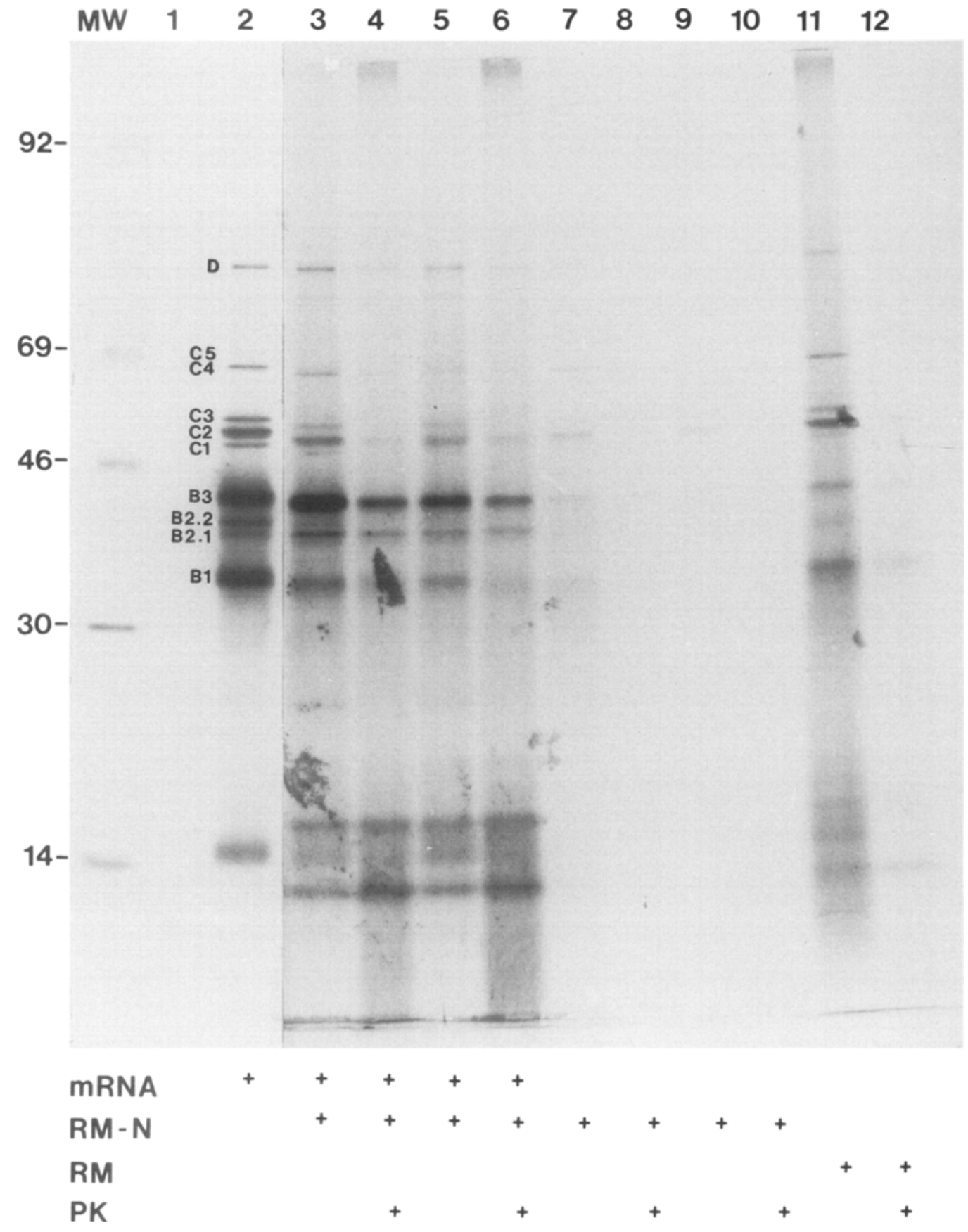


amide stock solutions were stored over mixedbed ion exchange resin (Amberlite MBI BDH) and the SDS was re-crystallized (18). The gel was pre-electrophoresed for 12 hours at $30 \mathrm{~mA}$ in separating gel buffer $(0.5 \mathrm{M}$ Tris- $\mathrm{HCl} \mathrm{pH} 8.45$, $0.1 \%$ SDS) in the presence of sodium thioglycolate, a charged nucleophilic scavanger, to eliminate residual acrylamide monomer $(18,22)$. Pre-electrophoresis is possible since the stacking and separating gels have the same Tris buffer.

Electrophoresis was performed at room temperature with $1 \mathrm{~mm}$ sodium thioglycolate in the cathode buffer. The samples were run into the stacking gel at $30 \mathrm{~V}$ and then run at $30 \mathrm{~mA}$ for 16 hours. The $\mathrm{B} 1$ hordein polypeptides were transferred to the chemically inert polyvinylidene difluoride (PVDF) membrane (Immobilon, Millipore) by semi-dry electroblotting (JKA Biotek. Denmark), according to (22). The low \% acrylamide separating gel was selected to enhance the transfer efficiency. The gel was washed for $10 \mathrm{~min}$ in transfer buffer, $50 \mathrm{~mm}$ borate $\mathrm{pH}$ $8.4,10 \% \mathrm{MeOH}$. The PVDF membrane was wetted in $100 \% \mathrm{MeOH}$ prior to electrotransfer for 2 hours at $4{ }^{\circ} \mathrm{C}$ with $0.4 \mathrm{~mA} / \mathrm{cm}^{2}$. The PVDF membrane was rinsed in $\mathrm{H}_{2} \mathrm{O}$ and dried under a stream of nitrogen. The hordein polypeptides were located by autoradiography and the excised areas of the PVDF membrane taken for sequencing on an Applied Biosystems sequencer model $477 \mathrm{~A}$. The sequencing runs were performed by Dr. KAREN G. WELINDER and ANNE BLICHER. The products of 14 cycles of $\mathrm{NH}_{2}$-terminal Edman degradation were then counted in a scintillation counter.

\section{RESULTS}

\subsection{In vitro synthesis and processing of hordein polypeptides}

Poly $\mathrm{A}^{+} \mathrm{RNA}$ prepared from developing Bomi endosperm was translated in the wheat germ system with ${ }^{35} \mathrm{~S}$ methionine, and the antihordein IgG immune precipitates analysed by SDS-PAGE (Fig. 1, lane 2). The primary hordein translation products have a mobility similar to the $\mathrm{B}, \mathrm{C}$ and $\mathrm{D}$ hordein polypeptides characteristic of Bomi endosperm (25). However, as previously demonstrated (5), the hordein polypeptides are synthesized as larger-sized precursors, which are co-translationally processed to a mature form in the presence of the E.R. (e.g. Fig.1, lane 11). The molecular weight shift is most apparent for the $\mathrm{C}$ hordein polypeptides. To examine the processing event in greater detail, rough and stripped microsomes were prepared according to BURR and BURR (7). The rough microsomes (RM) were first shown to be translationally active (Fig. 1. lane 11) and then stripped of most of their endogenous mRNA activity (RM-N) by micrococcal nuclease treatment (lane 7, 9). Reconstitution of these microsomes with endosperm poly $\mathrm{A}^{+} \mathrm{RNA}$ results in the synthesis of mature hordein polypeptides (lanes 3,5 ). The hordein polypeptides are cotranslationally transported into the lumen of the microsomes and have thereby become resistant to proteinase $\mathrm{K}$ digestion (lanes $4,6,12$ ). The translation activity of the RM assay (lane 11) was only $30 \%$ of that of the poly $\mathrm{A}^{+} \mathrm{RNA}$ with RM-N assay (lane 5), as judged by TCA precipitable counts, and hence the amount of protected hordein polypeptides was proportionally less (lane 12). The addition of microsomes to the assay was generally seen to be inhibitory to translation.

\subsection{Coupled transcription-translation of a B1 hordein gene}

The coding region of a B1 hordein gene, $\lambda$ hor2-4 (6) was cloned into the expression plasmid pDS6 (see section 2.5). The cloned

Figure 1. Hordein in vitro translation products of barley endosperm poly $A^{+} R N A$ and processing by ER microsomes. Poly $A^{+} R N A\left(0.06 A_{260} U\right)$ was translated in a $25 \mu l$ wheat germ assay (lane 2$)$. Barley $R M\left(0.23 A_{260} U\right)$ were similarly translated in vitro (lanes 11,12$)$ and after nuclease $S 7$ treatment as RM-N $\left(0.35 A_{260} U\right.$, lanes 7,8 ; $0.17 A_{260} U$, lanes 9,10$)$. Poly $A^{+} R N A$ was translated after reconstitution with $R M-N\left(0.17 A_{260} U\right.$, lanes 3,$4 ; 0.35$ $\mathrm{A}_{260} \mathrm{U}$, lanes 5, 6). A wheat germ translation without template is included (lane 1). Post-translational proteinase $\mathrm{K}$ treatment of aliquots from each assay is as indicated. The hordein polypepides in each assay were immunoprecipitated and analyzed by 10-15\% SDS-PAGE and fluorography. The film exposure for lanes 3-12 was approximately 3 fold longer than lanes 1 and 2 . 


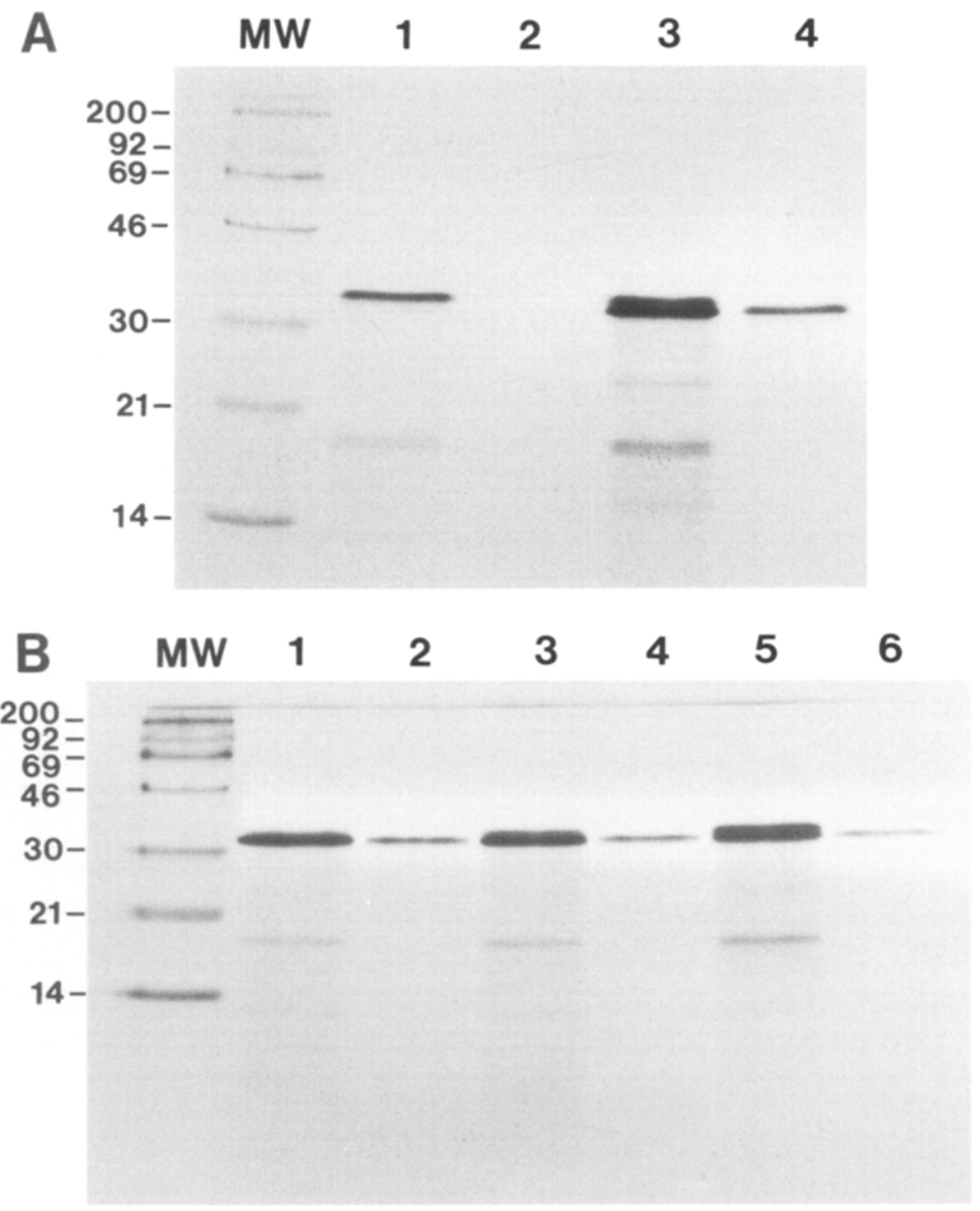

Figure 2. A B1 hordein polypeptide synthesized in vitro and processed by barley microsomes. A. mRNA, transcribed from $0.5 \mu \mathrm{g}$ pDS-hor $2-4$, was translated in the wheat germ system (lanes 1,2 ) and with the addition of $7 \mathrm{~A}_{260} / \mathrm{ml}$ of RM-N (lanes 3, 4). B. The concentration of RM-N added to the translation varied: $12 \mathrm{~A}_{260} \mathrm{U} / \mathrm{ml}$ (lanes 1, 2), $6 \mathrm{~A}_{260} \mathrm{U} / \mathrm{ml}$ (lanes 3, 4), $3 \mathrm{~A}_{260} \mathrm{U} / \mathrm{ml}$ (lanes 5, 6). Aliquots of each assay, given a post-translational proteinase $\mathrm{K}$ treatment, are in $\mathrm{A}$ : lanes 2,4 and $\mathrm{B}$ : lanes $2,4,6$. The translation products were analyzed by $18 \%$ (A) or $20 \%$ (B) SDS-PAGE and fluorography.

fragment extends $14 \mathrm{bp} 5$ ' upstream of the ATG translation start from the $\mathrm{Hpal}$ site and $16 \mathrm{bp} \mathrm{3}$ ' downstream of the TAA termination codon at the XbaI site. Capped mRNA was transcribed as described in section 2.6 and translated in the wheat germ system. Precursor B1 hordein was the single major translation product (Fig. 2A, lane 1) and was sensitive to proteinase $\mathrm{K}$ diges- tion (lane 2). Co-translational processing and transport of the mature form occurred in the presence of barley microsomes (lane 3) and led to proteinase $\mathrm{K}$ insensitivity (lane 4 ). Processing and transport of the $\mathrm{B} 1$ hordein polypeptide was dependent on microsome concentration in the assay (Fig. 2B), such that $12 \mathrm{~A}_{260} \mathrm{U} / \mathrm{ml} \mathrm{RM}-\mathrm{N}$ gave $90 \%$ processing, based on the relative inten- 

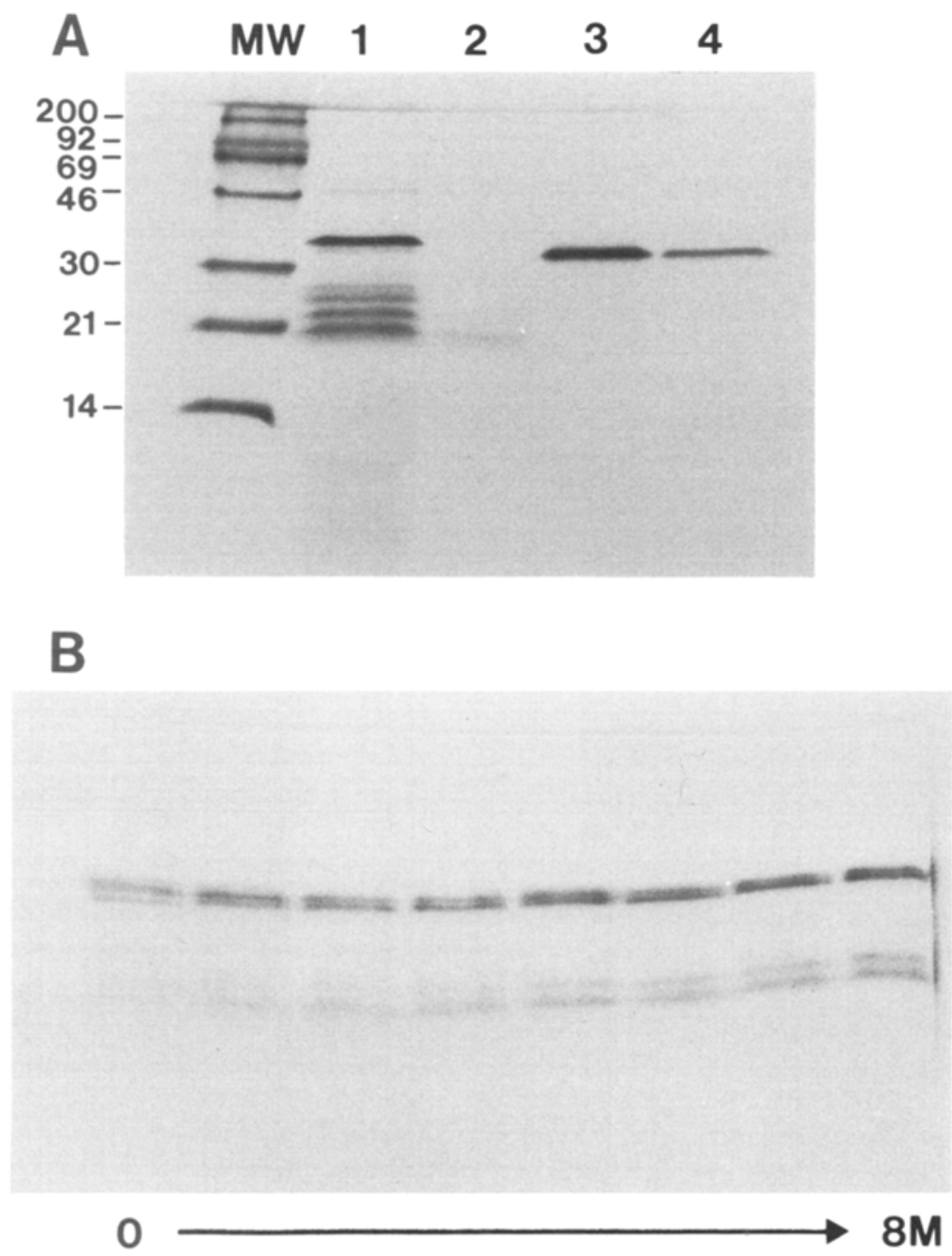

Figure 3. A B1 hordein polypeptide synthesized in vitro and processed by dog pancreas microsomes. A. mRNA, transcribed from $0.4 \mu \mathrm{g}$ pDS-hor $2-4$, was translated in a $30 \mu \mathrm{l}$ reticulocyte lysate assay (lanes 1,2 ) and with the addition of $10 \mu \mathrm{l}$ of dog pancreas RM-N (lanes 3,4). Aliquots of each assay were given a post-translational proteinase $\mathrm{K}$ treatment (lanes 2,4$)$. The translation products were analyzed by $18 \%$ SDS-PAGE and fluorography. $B$. Translation products, containing precursor and processed B1 hordein (A: lanes 1 and 3), were combined and replicate samples separated on an $18 \%$ SDS-PAGE containing a 0-8 $\mathrm{M}$ urea gradient.

sity of the two bands of approximately 31 and 29 $\mathrm{kd}$, in the autoradiogram (lane 1,2), while 3 $\mathrm{A}_{260} \mathrm{U} / \mathrm{ml} \mathrm{RM}-\mathrm{N}$ gave $50 \%$ processing to the mature form (lane 5,6).

Dog pancreas microsomes were similarly able to co-translationally process and transport B1 hordein polypeptides synthesized in the reticulocyte lysate system (Fig. 3A). Processing to the mature B1 hordein was $100 \%$ at microsome concentrations recommended by the manufacturer (lane 3, 4).

Electrophoretic conditions which might improve the separation of the precursor and the mature B1 hordein were investigated. Polyacrylamide concentrations of less than 18\% (see Fig. 1) failed to resolve the two forms. The influence 
Table I. Predicted N-chlorosuccinimide cleavage products of precursor and mature B1 hordein

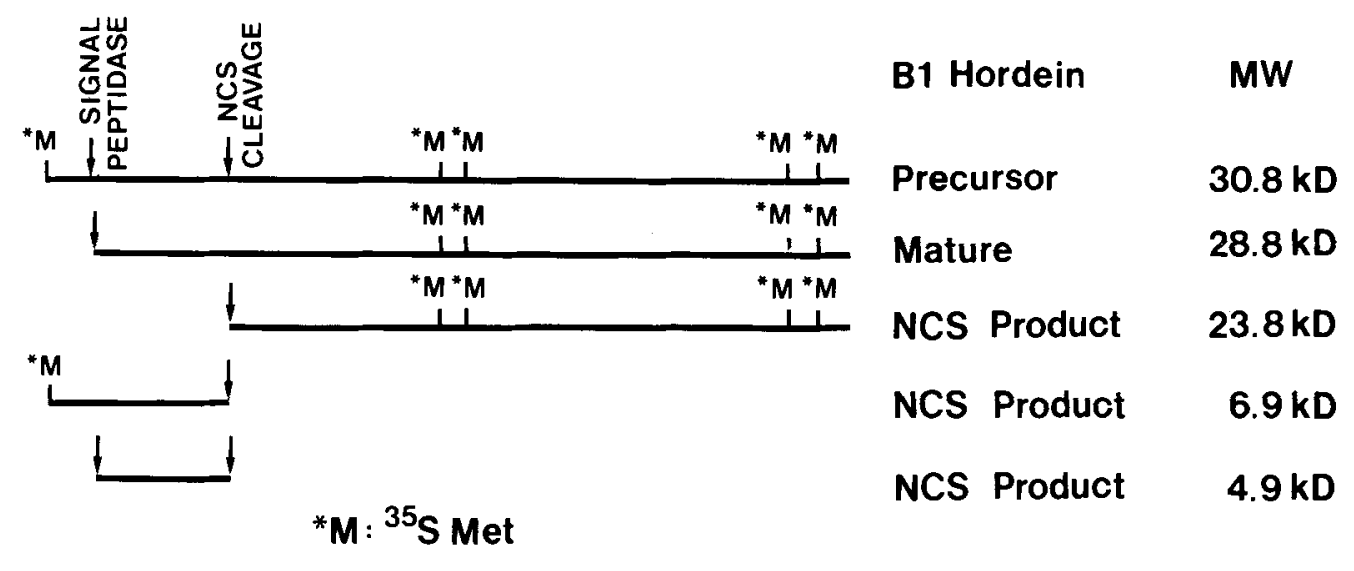

of the denaturing agent urea, on their electrophoretic mobility, was analysed on a transverse $0-8 \mathrm{M}$ urea gradient gel prepared in the high-Tris SDS-PAG system with a $5 \mathrm{~m}$ urea sample buffer (14). Urea was not found to improve the resolution of the two forms (Fig. 3B).

\subsection{B1 hordein processing examined by peptide mapping}

The peptide fragments released by N-chlorosuccinimide (NCS) cleavage of in vitro synthesized B1 hordein were analysed to confirm the co-translational processing event. The B1 hordein gene in pDS6 was transcribed and translated in vitro in either the wheat germ system, with or without barley microsomes, or in the reticulocyte lysate with the addition of dog pancreas microsomes. The products were separated by $10 \%$ SDS-PAGE, which does not resolve precursor and mature B1 hordein, and located by autoradiography. The gel pieces containing the hordein polypeptides were treated with NCS according to LiSCHWE and OCHS (20) and analysed by $18 \%$ SDS-PAGE and fluorography.

Under acidic conditions NCS specifically cleaves tryptophanyl peptide bonds by oxidative chlorination (28). Precursor Bl hordein, labelled with ${ }^{35} \mathrm{~S}$ methionine, should be cleaved after the single tryptophan residue at position 61 to yield ${ }^{35} \mathrm{~S}$ labelled peptides of $6.9 \mathrm{kd}$ and 23.8 $\mathrm{kd}$ (Table I). The $6.9 \mathrm{kd}$ peptide has a single methionine residue at the $\mathrm{NH}_{2}$-terminus. Signal peptide cleavage of the $\mathrm{B} 1$ hordein is predicted after residue 19 giving a $2 \mathrm{kd}$ signal peptide and the mature B1 hordein of $28.8 \mathrm{kd}$. NCS cleavage of mature $B 1$ hordein should yield an unlabelled N-terminal $4.9 \mathrm{kd}$ peptide and a labelled $23.8 \mathrm{kd}$ peptide. Since NCS cleavage of denatured proteins is partial (20), at least $50 \%$ of the precursor and mature B1 hordein polypeptides will remain uncleaved.

Analysis of the NCS cleavage products of precursor B1 hordein (Fig. 4 lanes 1, 5) showed the predicted $50 \%$ cleavage to $23.8 \mathrm{kd}$ and $6.9 \mathrm{kd}$ peptides [the latter migrating with an abnormally high mobility]. The relative labelling intensities of the products correlated with their methionine content (Table I). $40 \%$ to $60 \%$ processing of the precursor to mature $\mathrm{B} 1$ hordein by barley microsomes led to a reduced yield of the $6.9 \mathrm{kd}$ peptide (lanes 2,4 ), which was completely absent when the precursor had been digested with proteinase $K$ (lane 3 ). Where in vitro processing of $\mathrm{Bl}$ hordein was $100 \%$, as was the case with dog microsomes, the $6.9 \mathrm{kd}$ peptide was also absent (lanes 6, 7).

\subsection{Radiosequencing a $B 1$ hordein polypeptide}

Precursor and mature B1 hordein polypeptides were radiosequenced to determine the precise signal peptide cleavage site. Since purified $\mathrm{B} 1$ hordein was found to be blocked to Edman degradation (26), particular care was 
taken to select protocols which minimized the occurence of $\mathrm{NH}_{2}$-terminal blocking of proteins. The B1 hordein gene in pDS6 was transcribed and translated in the wheat germ system, with and without barley microsomes. The polypeptides were synthesized with ${ }^{3} \mathrm{H}$-isoleucine to enable the $\mathrm{N}$-terminal sequence of precursor and mature $\mathrm{B} 1$ hordein polypeptides to be distinguished. The translation products were separated by SDS-PAGE, blotted onto PVDF paper and subjected to 14 cycles of automated Edman degradation (Fig. 5). In the presence of barley microsomes processing was approximately $67 \%$, although it was not possible to separate the precursor and mature forms for sequencing. The radiosequence of these products (Fig. 5B) thus reflects a combination of precursor and mature B1 hordein polypeptides. The contribution of the precursor in Fig. 5B can be removed by proportional subtraction of Fig. $5 \mathrm{~A}$ to show the amount of radioactivity due to the mature $\mathrm{B} 1$ hordein sequence (Fig. 5C). The radiosequence thus confirmed the predicted site of signal peptide cleavage.

\section{DISCUSSION}

When poly $\mathrm{A}^{+} \mathrm{RNA}$ from barley endosperm is translated in vitro, the co-translational transport of the hordein polypeptides across the microso-

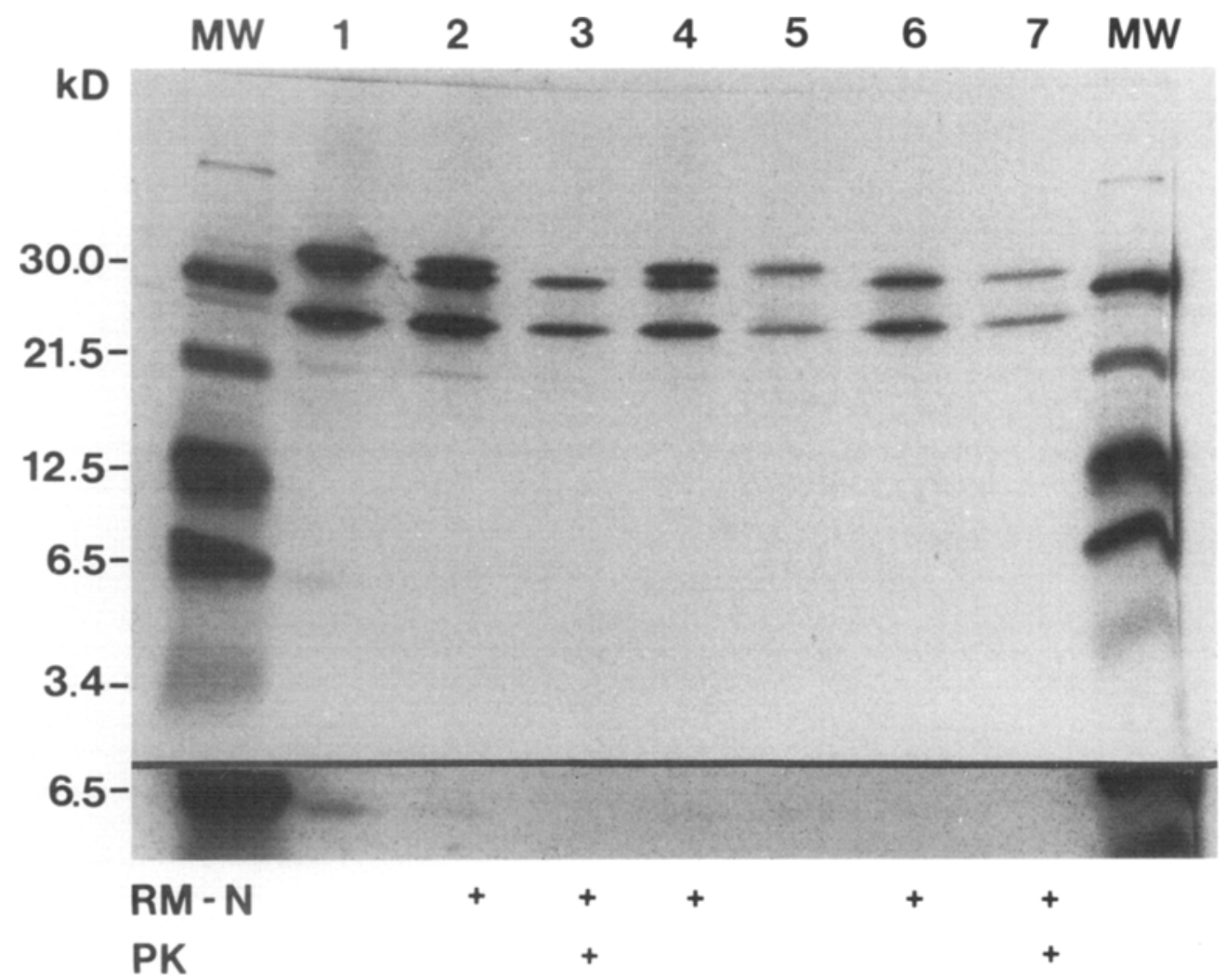

Figure 4. N-Chlorosuccinimide cleavage of a $\mathrm{B} 1$ hordein polypeptide. $\mathrm{mRNA}$, transcribed from $0.5 \mu \mathrm{g} \mathrm{pDS}-$ hor $2-4$, was translated in either the wheat germ system (lane 1) and with added barley RM-N ( $7 \mathrm{~A}_{260} \mathrm{U} / \mathrm{ml}$, lanes 2,$3 ; 3$ $A_{260} \mathrm{U} / \mathrm{ml}$, lane 4) or in the reticulocyte lysate (lane 5) and with added dog pancreas RM-N (lanes 6, 7). Post-translational proteinase $\mathrm{K}$ treatment of aliquots of some assays are included (lanes 3, 7). The translation products were separated by $10 \%$ SDS-PAGE and the gel fragments containing B1 hordein polypeptides were subjected to NCS cleavage and the products analyzed by $18 \%$ SDS-PAGE and fluorography. A longer film exposure of part of the gel is shown below. 


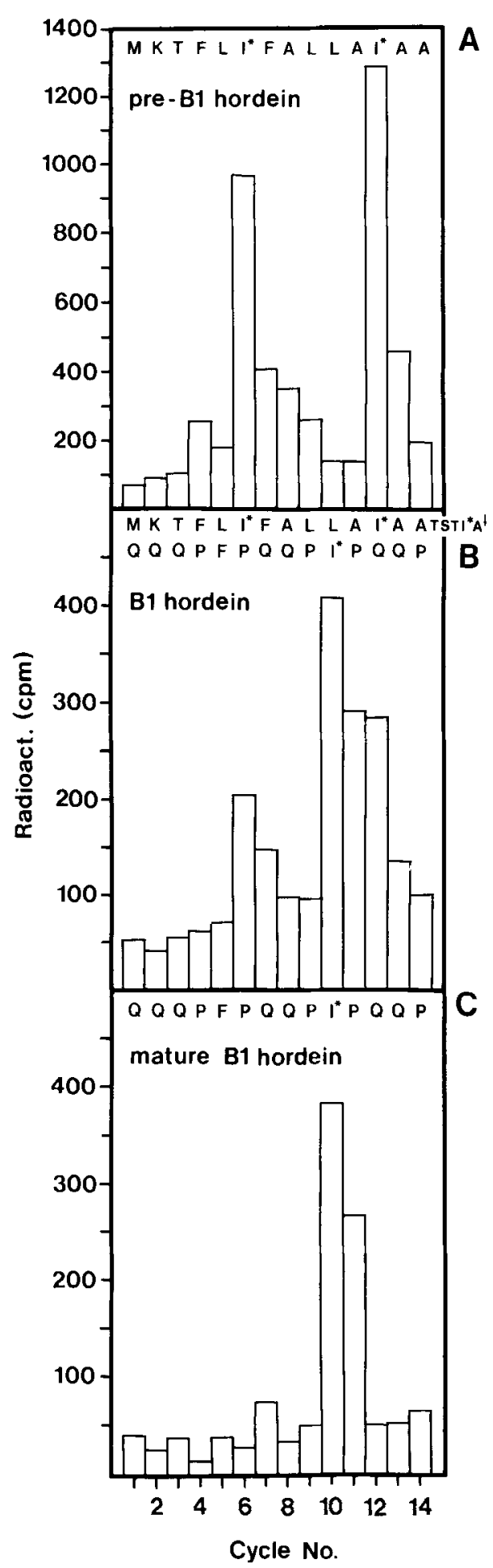

mal membrane, and their consequent protection from protease digestion, can be clearly demonstrated. However a change in SDS-PAGE mobility, as a result of signal peptide cleavage, is clearly apparent only in the $\mathrm{C}$ hordein polypeptides. Characterization of a $\mathrm{C}$ hordein gene and comparison with the $\mathrm{NH}_{2}$-terminal sequence of mature $\mathrm{C}$ hordein polypeptides, has confirmed the presence of a cleavable signal peptide (12).

In order to study the processing events which accompany the transport of $B$ hordein across the $E R$, the $B 1$ hordein gene $\lambda$ hor 2-4 (6) cloned in the vector pDS6 was expressed in vitro. The major translation product, synthesized in either the wheat germ system or the reticulocyte lysate, was the B1 hordein polypeptide. Translation in the presence of either barley microsomes or dog pancreas microsomes gave a second form, protected from protease attack and of lower molecular weight.

Electrophoretic resolution of the precursor and processed forms was limited. A variety of denaturing and reducing reagents was tested, together with different acrylamide concentrations, without significantly improving their separation. Protein modification, which may accompany protein transport across the ER and

Figure 5. BI hordein radiosequencing. pDS-hor2-4 was transcribed and translated in vitro in the wheat germ system and with added barley RM-N. The synthesized B1 hordein polypeptides, labelled with ${ }^{3} \mathrm{H}$-isoleucine, were separated by SDS-PAGE, electroblotted onto PVDF membrane and subjected to 14 cycles of Edman degradation. The $\mathrm{NH}_{2}$-terminal radiosequence of the B1 hordein mRNA primary translation product is shown in $A$ and the expected amino acid sequence given at the top of the panel. The position of the radioactive isoleucines is marked with asterisks. Panel B presents the radiosequence of a mixture of $67 \%$ processed translation product and $33 \%$ precursor. The two expected amino acid sequences and the position of the labelled isoleucine residues is given at the top of the panel. The signal peptide cleavage point is indicated with an arrow. By removing the contribution of the precursor sequence from the histogram of B by proportional subtraction, the mature B1 hordein sequence is derived and presented in panel C. 
lead to an increase in molecular weight, includes the addition of oligosaccharide side chains to the protein backbone. In all eucaryotes, N-glycosylation occurs at asparagine residues in the consensus sequence Asn X Ser/Thr (13). Since this sequence is absent from the $\mathrm{B} 1$ hordein, the absence of a significant mobility shift of the processed $\mathrm{B} 1$ hordein cannot be attributed to this common type of glycosylation. One may conclude that SDS solubilized precursor and processed $\mathrm{B} 1$ hordein polypeptides have a rather similar electrophoretic mobility.

The location of the processing event was determined by $\mathrm{N}$-chlorosuccinimide peptide mapping. NCS cleavage of ${ }^{35} \mathrm{~S}$ methionine-labelled precursor $\mathrm{B} 1$ hordein released a $6.9 \mathrm{kd}$ peptide labelled with a single $\mathrm{NH}_{2}$-terminal methionine, as predicted from the deduced sequence. Signal peptide cleavage of the B1 hordein, as the co-translational processing event, was indicated by the disappearance of this labelled $\mathrm{NH}_{2}$-terminal peptide. To determine the exact processing site, the precursor and processed $\mathrm{B} 1$ hordein polypeptides, synthesized in the wheat germ system and in the presence of barley microsomes, were subjected to $\mathrm{NH}_{2}$-terminal radiosequencing. Although $\mathrm{B} 1$ hordein processing by barley microsomes was not $100 \%$ efficient and the proteins subjected to sequencing were a mixture of precursor and mature forms, it was considered desirable to analyse the products of an in vitro processing event which most closely resembled their in vivo synthesis. Comparison of the radiosequence data from precursor and processed $\mathrm{B} 1$ hordein translation products confirmed the presence of a 19 amino acid signal peptide with co-translational cleavage to the mature form.

The combination of in vitro transcription of the $\mathrm{B} 1$ hordein gene and subsequent translation and polypeptide transport into microsomes derived from barley endosperm ER, provides a system for examining the components which contribute to the transport and processing events. The presence of signal recognition particles, primary components in the recognition of signal peptides of secreted proteins and their subsequent association with the ER, has been demonstrated in plants (9). However, other membrane components, such as the signal recognition particle receptor (21), have yet to be identified in plant membranes.

\section{ACKNOWLEDGEMENTS}

We thank Dr. ANDERS BRANDT for helpful discussions throughout the course of this work and for critically reading the manuscript. We gratefully acknowledge the contribution of Dr. KAREN G. WELINDER and ANNE BLICHER of the Institute for Biochemical Genetics, Copenhagen University, Denmark, in performing the radiosequencing with the instrumentation supplied by Teknologistyrelsen. We thank NiNA RASMUSSEN and ANN-SOFISTEINHOLTZ for figure preparation. SUSAN M. MADRID acknowledges receipt of financial support in the form of a stipendium from the Danish Biotechnology Center for Plants. This work was supported by the Biotechnological Action Programme of the Commission of the European Communitities with contract no. BAP-0091-DK to Professor D. VON WETTSTEIN.

\section{REFERENCES}

1. ANDERSON, D. \& G. BLOBEL: Immuneprecipitation of proteins from cell-free translations. Methods in Enzymology 96, 111-120 (1983)

2. Aviv, H. \& P. Leder: Purification of biologically active globin messenger RNA by chromotography on oligothymidylic acid cellulose. Proc. Natl. Acad. Sci. USA 69: 1408-1411 (1972)

3. BIRNBoIM, H.C. \& J. DoLY: A rapid alkaline extraction procedure for screening recombinant plasmid DNA. Nucleic Acids Res. 7, 1513-1523 (1979)

4. BRANDT, A. \& J. INGVERSEN: In vitro synthesis of barley endosperm proteins on wild type and mutant templates. Carlsberg Res. Commun. 41, 312320 (1976)

5. BRANDT, A. \& J. INGVERSEN: Isolation and translation of hordein messenger RNA from wild type and mutant endosperms in barley. Carlsberg Res. Commun. 43, 451-469 (1978)

6. BRandt, A., A. Montembault, V.CAmeron-Mills \& S.K. RASMUSSEN: Primary structure of a B1 hordein gene from barley. Carlsberg Res. Commun. 50, 333-345 (1985)

7. BURR, F.A.\& B. BURR: In vitro uptake and processing of prezein and other maize preproteins by maize membranes. J. Cell Biol. 90, 427-434 (1981) 
8. Cameron-Milis, V. \& A. Brandt: A $\gamma$-hordein gene. Plant Mol. Biol. 11, 449-461 (1988)

9. Campos, N., J. Palau, M. Torrent \& D. Ludevid: Signal recognition-like particles are present in maize. J. Biol. Chem. 263, 9646-9650 (1988)

10. Chamberlain, J.P.: Fluorographic detection of radioactivity in polyacrylamide gels with the water-soluble fluor, sodium salicylate. Anal. Biochem. 98, 132-135 (1979)

11. Dierks-Ventling, C. \& K. Cozens: Immunochemical crossreactivity between zein, hordein and gliadin. FEBS Lett. 142, 147-150 (1982)

12. ENTWISTLE, J.: Primary structure of a C-hordein gene from barley. Carlsberg Res. Commun. 53, 247-258 (1988)

13. Faye, L., K.D. Johnson, A. Sturm \& M.J. ChrisPeELS: Structure, biosynthesis and function of asparagine-linked glycans on plant glycoproteins. Physiol. Plant. 75, 309-314 (1989)

14. FLING, S.P.\& D.S. GREGERSON: Peptide and protein molecular weight determination by electrophoresis using a high-molarity Tris buffer system without urea. Anal. Biochem. 155, 83-88 (1986)

15. Giese, H., B. ANDERSEN \& H. DOLL: Synthesis of the major storage protein, hordein, in barley. Pulse-labeling study of grain filling in liquid-cultured detached spikes. Planta 159, 60-65 (1983)

16. Hanahan, D: Studies on transformation of Escherichia coli with plasmids. J. Mol. Biol. 166, 557-580 (1983)

17. HEIJNE, G. voN: On the hydrophobic nature of signal sequences. Eur. J. Biochem. 116, 419-422 (1981)

18. Hunkapiller, M.W., E. Lujan, F. Ostrander \& L.E. HooD: Isolation of microgram quantities of proteins from polacrylamide gels for amino acid sequence analysis. Methods in Enzymology 91, 227-236 (1983)

19. LAEMML, U.K: Cleavage of structural proteins during the assembly of the head of bacteriophage T4. Nature 227, 680-685 (1970)

20. Lischwe, M.A. \& D. OCHS: A new method for partial peptide mapping using $\mathrm{N}$ - chlorosuccinimide/urea and peptide silver staining in sodium dodecyl sulfate-polyacrylamide gels. Anal. Biochem. 127, 453-457 (1982)

21. MeYer, D.I., E. KRAUSE \& B. DobberSTEIN: Secretory protein translocation across membranes - the role of the 'docking protein'. Nature 297, 647-650 (1982)

22. Ploug, M., A.L. Jensen \& V. Barkholt: Determination of amino acid compositions and $\mathrm{NH}_{2}$-terminal sequences of peptides electroblotted onto PVDF membranes from Tricine-sodium dodecyl sulfate-polyacrylamide gel electrophoresis: Application to peptide mapping of human complement component C3. Anal. Biochem. 181, 33-39 (1989)

23. Radloff, R., W. Bauer \& J. Vinograd: A dyebuoyant-density method for the detection and isolation of closed circular duplex DNA: the closed circular DNA in HELA cells. Proc. Natl. Acad. Sci. USA 57, 1514-1524 (1967)

24. ROBERTS, B.E. \& B.M.PATTERSON: Efficient translation of tobacco mosaic virus RNA and rabbit globin 9S RNA in a cell free system from commercial wheat germ. Proc. Natl. Acad. Sci. USA 70, 2330-2334 (1974)

25. SCHмrтt, J.M:: Purification of hordein polypeptides by column chromotography using volatile solvents. Carlsberg Res. Commun. 44, 431-438 (1979)

26. SChmitt, J.M. \& I. SvendSEn: Amino acid sequences of hordein polypeptides. Carlsberg Res. Commun. 45, 143-148 (1980)

27. SCHÄGGER, H. \& G. vON JAGOW: Tricine-sodium dodecyl sulfate-polyacrylamide gel electrophoresis for the separation of proteins in the range from 1 - 100kDa. Anal. Biochem. 166, 368-379 (1987)

28. SheChTER, Y., A. PATCHORnIK \& Y. BurStein: Selective chemical cleavage of tryptophanyl peptide bonds by oxidative chlorination with $\mathrm{N}$-chlorosuccinimide. Biochemistry 15, 5071-5075 (1976)

29. Stueber, D., I. Ibrahimi, D. Cutler, B. DobberSTEIN \& H. BUJARD: A novel in vitro transcriptiontranslation system: accurate and efficient synthesis of single proteins from cloned DNA sequences. EMBO J. 3, 3143-3148 (1984)

30. SøRENSEn, M.B., V. CAMERon-Mills \& A. BRANDT: Transcriptional and port-transcriptional regulation of gene expression in developing barley endosperm. Mol. Gen. Genet. 217, 195-201 (1989)

31. WeBer, E. \& A. BRANDT: Species specific signal peptide cleavage of plant storage protein precursors in the endoplasmic reticulum. Carlsberg Res. Commun. 50, 299-308 (1985)

Accepted by H. KLENOW 